\title{
Correction to: Decision Analysis: Omadacycline Relative to Moxifoxacin Among Hospitalized Community-Acquired Bacterial Pneumonia Patients at Risk of Clostridioides difcile Infection
}

\author{
Thomas P. Lodise ${ }^{1} \cdot$ Rohit Mistry $^{2} \cdot$ Kate Young $^{3} \cdot$ Kenneth LaPensee ${ }^{4}$
}

Published online: 28 April 2021

(c) The Author(s) 2021

\section{Correction to: \\ Clinical Drug Investigation (2021) 41:269-275 \\ https://doi.org/10.1007/s40261-021-01005-w}

The article Decision Analysis: Omadacycline Relative to Moxifloxacin Among Hospitalized Community-Acquired Bacterial Pneumonia Patients at Risk of Clostridioides difficile Infection, written by Thomas P. Lodise, Rohit Mistry, Kate Young and Kenneth LaPensee, was originally published Online First without Open Access. After publication in volume 41 , issue 3, page 269-275 the author decided to opt for Open Choice and to make the article an Open Access publication. Therefore, the copyright of the article has been changed to (C) The Authors 2021 and this article is licensed under a Creative Commons Attribution-NonCommercial 4.0 International License, which permits any non-commercial use, sharing, adaptation, distribution and reproduction in any medium or format, as long as you give appropriate credit to the original author(s) and the source, provide a link to the Creative Commons licence, and indicate if changes were made. The images or other third party material in this article are included in the article's Creative Commons licence, unless indicated otherwise in a credit line to the material. If material is not included in the article's Creative Commons licence and your intended use is not permitted by statutory regulation or exceeds the permitted use, you will need to obtain permission directly from the copyright holder. To view a copy of this licence, visit http://creativecommons. org/licenses/by-nc/4.0/.

The original article has been corrected.

Open Access This article is licensed under a Creative Commons Attribution-NonCommercial 4.0 International License, which permits any non-commercial use, sharing, adaptation, distribution and reproduction in any medium or format, as long as you give appropriate credit to the original author(s) and the source, provide a link to the Creative Commons licence, and indicate if changes were made. The images or other third party material in this article are included in the article's Creative Commons licence, unless indicated otherwise in a credit line to the material. If material is not included in the article's Creative Commons licence and your intended use is not permitted by statutory regulation or exceeds the permitted use, you will need to obtain permission directly from the copyright holder. To view a copy of this licence, visit http://creativecommons.org/licenses/by-nc/4.0/.
The original article can be found online at https://doi.org/10.1007/ s40261-021-01005-w.

Thomas P. Lodise

Thomas.Lodise@acphs.edu

1 Albany College of Pharmacy and the Health Sciences, 106 New Scotland Avenue, Albany, NY 12189, USA

2 PAREXEL Access Consulting, London, UK

3 PAREXEL Access Consulting, Waltham, MA, USA

4 Paratek Pharmaceuticals, Inc, King of Prussia, PA, USA 